\title{
Community Standards in Obscenity Adjudication
}

As part of the system of obscemity regulation set forth in Miller $v$. California $^{1}$ and companion cases ${ }^{2}$ and refined by subsequent Supreme Court decisions, the concept of contemporary community standards has received considerable judicial ${ }^{3}$ and critical $^{4}$ attention. The attention generally has focused on whether to employ national or local standards ${ }^{5}$ and on the constitutionality of using commumity standards of any kind. ${ }^{6}$ The Court's own attitude lias been clarified somewliat by two recent decisions ${ }^{7}$ whicli indicate that community standards have little to do with geographic boundaries and are not "standards" in the usual meaning of the term. ${ }^{8}$ It is the thesis of this Comment that the Supreme Court's current conception of community standards performs a valuable shielding function within the Miller system and, therefore, should be retamed despite the term's inherent vagueness.

Part I summarizes the historical development of community standards in case law prior to 1973 and then describes the Miller mechanism for identifying "obscene" material. Part II analyzes the role of community standards in the Miller scheme, particularly witl reference to the

1. 413 U.S. 15 (1973).

2. Paris Adult Theatre I v. Slaton, 413 U.S. 49 (1973); Kaplan v. California, 413 U.S. 115 (1973); United States v. Twelve 200-Ft. Reels of Super 8MM. Film, 413 U.S. 123 (1973); United States v. Orito, 413 U.S. 139 (1973); Heller v. New York, 413 U.S. 483 (1973); Roaden v. Kentucky, 413 U.S. 497 (1973); Alexander v. Virginia, 413 U.S. 836 (1973) (per curiam).

3. The cases are too numerous to cite usefully. The Supreme Court alone has discussed community standards on numerous occasions since it first uttered the phrase in Roth v. United States, 354 U.S. 476, 489 (1957). See Pinkus v. United States, 98 S. Ct. 1808, 1810-16 (1978); Snith v. United States, 431 U.S. 291 (1977); Hamling v. United States, 418 U.S. 87, 104-06 (1974); Miller v. United States, 413 U.S. 15, 30-33 (1973); Jacobellis v. Ohio, 378 U.S. 184, 193 (1964); Manual Enterprises, Inc. v. Day, 370 U.S. 478, 488 (1962).

4. See, e.g., Edelstein \& Moth, Collateral Problems in Obscenity Regulation: A Uniform Approach to Prior Restraints, Community Standards, and Judgment Preclusion, 7 SETON HALL L. REv. 543, 566-71 (1976); Lockhart \& McClure, Censorship of Obscenity: The Developing Constitutional Standards, 45 MINN. L. REv. 5, 108-16 (1960); O'Meara \& Shaffer, Obscenity in the Supreme Court: A Note on Jacobellis v. Ohio, 40 Notre DAME Law. 1 (1965); Schauer, Reflections on "Contemporary Community Standards": The Perperuation of an Irrelevant Concept in Obscenity Law, 56 N.C.L. Rev. 1 (1978); Shugrue, An Atlas for Obscenity: Exploring Community Standards, 7 CrelGhton L. Rev. 157 (1974); Note, Community Standards, Class Actions, and Obscenity under Miller v. California, 88 HARv. L. Rev. 1838 (1975) [hereinafter Class Actions]; Note, The Geography of Obscenity's Contemporary Community Standard, 8 WAKE FOREST L. REv. 81 (1971).

5. See text accompanying notes $34-40$ infra.

6. See Lockhart \& McClure, supra note 4, at 112-14; Schauer, supra note 4.

7. Pinkus v. United States, 98 S. C.. 1808 (1978); Smith v. United States, 431 U.S. 291 (1977).

8. See note 26 infra. 
allocation of issues between questions of fact and questions of law. 9 The community standards concept is an essential element of the Miller scheme because it limits the scope of judicial control of the obscenity test and thus protects material against suppression. Offsetting this, however, is the creation of further uncertainty along the already blurred line separating speech from "nonspeech." This impairs the goal of giving fair notice to primary actors of what they legally may publisl or distribute. The uncertainty, vagueness, and notice problems are discussed in Part III. The Comment concludes that, on balance, the community standards concept should be retained, particularly if the other benclimarks of the Miller test-serious value, the "liardcore" limitation, and the specificity requirement-can be articulated more precisely.

\section{EVOLUTION OF "CONTEMPORARY COMMUNITY STANDARDS"}

\section{A. The Pre-Roth Approach ${ }^{10}$}

The general subject of obscenity did not become a part of the Supreme Court's first amendinent doctrine until the 1957 decision, Roth v. United States. ${ }^{11}$ Earlier Supreme Court ${ }^{12}$ and lower court ${ }^{13}$ opinions had produced a widely accepted test for discerning obscenity that was developed througli statutory ${ }^{14}$ rather than constitutional analysis. The

9. Discussion will be confined to printed matter-books, magazines, newspapers, etc.-and films. Live perfornance, see, e.g., California v. Larue, 409 U.S. 109 (1972), and broadcasting, see, e.g., FCC v. Pacifica Foundation, 98 S. Ct. 3026 (1978), cases involve significant complications in obscenity doctrine that are beyond the scope of this Comment. Pacifica, in particular, broaches the new (for the Supreme Court) subject of permissible regulation of nonobscene sexually oriented naterial-material, in the words of Justice Stevens, that is "indecent but not obscene." Id. at 3030.

10. For a niore detailed treatment of the history of obscenity law and the first amendment, see Schauer, supra note 4, at 3-13.

11. 354 U.S. 476 (1957). Doubleday \& Co. v. New York, 335 U.S. 848 (1948), had raised the broad issue presented in Roth-whether and in what manner obscenity was subject to first amendment protection - but the Court divided four to four and produced no opinion.

12. See, e.g., Swearingen v. United States, 161 U.S. 446 (1896); Grimm v. United States, 156 U.S. 604 (1895).

13. See, e.g., United States v. Dennett, 39 F.2d 564 (2d Cir. 1930); United States v. Wightman, 29 F. 636 (W.D. Pa. 1886). See generally F. Schauer, The LaW OF OBscenity ch. 1 (1976).

14. The most notable, and perhaps most often used, obscenity statute was the Comstock Act, enacted in 1873. In its present forn, 18 U.S.C. $§ 1461$ (1978), it has been a frequently used basis for Supreme Court obscenity decisions. See, e.g., Pinkus v. United States, 98 S. Ct. 1808 (1978); Hamling v. United States, 418 U.S. 87 (1974); United States v. Reidel, 402 U.S. 351 (1971); Roth v. United States, 354 U.S. 476 (1957). Section 1461 provides in relevant part:

Every obscene, lewd, lascivious, indecent, filthy or vile article, natter, thimg, device, or substance ... [i]s declared to be nonmailable matter and shall not be convcyed in the inails or dehivered from any post office or by any letter carrier. Whoever knowingly uses the mails for the inailing, carriage in the inails, or dehivery of anything declared by this 
community standards concept made its first appearance in this context in an opinion by then District Judge Learned Hand in United States $v$. Kennerly:

If there be no abstract definition such as I have suggested, should not the word "obscene" be allowed to indicate the present critical point in the compromise between candor and shame at which the community may have arrived here and now?

[I] $t$ would seein that a jury should in each case establish the standard much as they do in cases of negligence. To put thought in leash to the average conscience of the time is perhaps tolerable, but to fetter it by the necessities of the lowest and least capable seems a fatal policy. ${ }^{15}$

This passage represents a reaction to the prevailing Hicklin ${ }^{16}$ obscenity test that judged material on the basis of the effect of its most offending excerpts on the most vulnerable viewer. In time, the Kennerly formulation came to predominate; the Hicklin test largely had been discarded by the tinie of Roth. ${ }^{17}$

Though not framed in response to a first amendment argument, the Kennerly opinion presaged the functional role that "contemporary community standards" would later play in constitutional obscenity adjudication. First, Judge Hand saw the "average conscience" as an acceptably flexible reference point from which to view challenged materials. It freed literature from what he saw to be the dead hand of "mid-Victorian morahity,"18 represented by Hicklin's focus on the most sensitive person, while accommodating the legislatively perceived need for some regulation. ${ }^{19}$ The Roth Court viewed the community standards concept as serving essentially the same role. ${ }^{20}$ Second, $\mathrm{m}$ addition to allowing the precise standard to change over time, the Kennerly formulation made it more difficult to find material to be obscene. A judge or jury no longer could look to its "tendency ... to deprave and cor-

section . . . to be nonmailable, or knowingly causes to be delivered by inail according to the direction thereon . . . slall be fined not more than $\$ 5,000$ or imprisoned not more than five years, or both, for the first offeuse, and shall be fined not more than $\$ 10,000$ or imprisoned not more than ten years, or both, for eaclı sucl offense thereafter.

18 U.S.C.A. § 1461 (West Supp. 1978).

The statute lias been construed as reaching all "obscenity" as the term is defined by the Supreine Court; its scope thus extends to the constitutional limit of permissible regulation. See, e.g., Marks v. United States, 430 U.S. 188 (1977).

15. 209 F. 119, 120-21 (S.D.N.Y. 1913).

16. Regina v. Hicklin, L.R. 3 Q.B. 360 (1868).

17. See Roth v. United States, 354 U.S. at 489.

18. United States v. Kennerly, 209 F. at 120. Judge Hand's concern was that a standard not be temporally "frozen"-i.e., that allowance for clianging mores somehow be incorporated in the test.

19. This Comment will not take up the broad and extensively covered issue of the reasons for or wisdon of regulating obscenity. For a comprelensive collection of the major critical commentary, see Project, An Empirical Inquiry into the Effects of Miller v. California on the Control of Obscenity, 52 N.Y.U. L. REV, 810, 820 n.3 (1977).

20. See text accoinpanying notes 25-27 infra. 
rupt those whose minds are open to such influences,"21 which previously enabled the trier of fact to condemn any inaterial that might offend soine imaginable reader or viewer. Under Kennerly, the "average" sensibility had to be considered and, in theory, personal reactions put aside. ${ }^{22}$ Third, Judge Hand recognized that, like the tort law concept of negligence, the term "obscenity" could not be generalized coherently, but could be discerned only in particular cases. This analogy was to appear again in the most recent Supreme Court obscenity opinions. ${ }^{23}$

Following a long and confusing excursus into evidentiary ${ }^{24}$ and geographical limitations on the contemporary community standards factor of the constitutional obscenity test, the Court lias attempted to reestablish the primacy of these tliree functions. Nonetheless, the interim period of doctrimal ambivalence left a lasting mark; confusion about the terms "comınunity" and "standards" persists.

\section{B. From Roth to Miller}

Roth v. United States ${ }^{25}$ established the theoretical foundation on which all subsequent constitutional obscenity adjudication is premised: that which is "obscene" is not "speeclr" and is, therefore, not protected by the first amendınent. ${ }^{26}$ The process of placing certam material in

21. Regina v. Hicklin, L.R. 3 Q.B. at 371.

22. This note has been sounded repeatedly throughout the history of obscenity jurisprudence after 1957. See, e.g., Pinkus v. United States, 98 S. Ct. 1808, 1813 (1978); Roth v. United States, 354 U.S. at 489.

23. See Pinkus v. United States, 98 S. Ct. 1808, 1813 (1978); Smith v. United States, 431 U.S. 291, 308 (1977); Hamling v. United States, 418 U.S. 87, 104-05 (1974).

24. See note 33 and accompanying text infra.

25. 354 U.S. 476 (1957).

26. This approach, called the "definitional" or "two-tiered" theory of obscenity, has been subject to voluminous comment. See generally Finnis, "Reason and Passion": The Constitutional Dialectic of Free Speech and Obscenity, 116 U. PA. L. REv. 222 (1967); Kalven, The Metaphysics of the Law of Obscenity, 1960 SuP. CT. REv. 1; Lockhart \& McClure, supra note 4, at 19-30. The relative nierits of the definitional theory and its chief competitor, the "variable obscenity" theory, see Lockhart \& McClure, supra note 4, at 66-88; TECHNICAL REPORT OF THE COMMISSION ON OBSCENITY AND PoRnography (1970), are beyond the scope of this Comment. An argument can be made that the Court has, on some occasions, imphicitly moved in the direction of the variable obscenity theory, which exphicitly evaluates material in the context of its purpose, manner of distribution, and audience in order to determine whether it is obscene. Variable obscenity was most noticeably suggested by several decisions of the 1960's. Examples include Stanley v. Georgia, 394 U.S. 557, 568 (1969) (state power to regulate obscenity does not extend to possession in the home of otherwise obscene inaterial); Ginsberg v. New York, 390 U.S. 629, 638 (1968) (prurient appeal of niaterial distributed to minors to be gauged not according to the "average person" but to "such minors"); Mishkin v. New York, 383 U.S. 502, 508-09 (1966) (where material was intended for or distributed to a clearly defined deviant group, prurient appeal to be evaluated not according to the "average person" but to meinbers of that group); Ginzburg v. United States, 383 U.S. 463, 470-71 (1966) ("pandering" is relevant to the obscenlty question in close cases).

Ginzburg has been reaffirmed several times, Pinkus v. United States, 98 S. Ct. 1808, 1815 (1978); Splawn v. Califorma, 431 U.S. 595, 598 (1977); Hamling v. United States, 418 U.S. 87, 130 
the unprotected cateogry-obscenity - was a constitutionally sensitive task for which the Hicklin test was inadequate. In its stead, the Roth Court substituted a functional equivalent of Judge Hand's Kennerly formulation: "whether to the average person, applying conteniporary community standards, the dominant theme of the material taken as a whole appeals to prurient interest."27

Two other aspects of the Roth decision are notable. First, the justification for according obscenity no first amendment protection was its total lack of "redeemmg social importance." 28 Whatever values the first amendment was designed to safeguard, obscenity furthers none of them. ${ }^{29}$ The Roth test was, in effect, a proxy rule for identifyimg valueless, and only valueless, sexually-oriented material. There was, therefore, no need for the government to monitor "value" per se, because in theory, the test itself would place worthy matter beyond governmental reach. ${ }^{30}$

Second, Justice Harlan's concurring and dissenting opinion inade it evident that no formulation was to be trusted totally to perform the delicate separation between speech and nonspeech. Appellate review

(1974), as has Mishkin, Pinkus v. United States, 98 S. Ct. at 1813; Hamling v. United States, 418 U.S. at 128-30. Ginsberg has been affirmed by negative implication, Pinkus v. United States, $98 \mathrm{~S}$. Ct. at 1812. But, in Miller, the Court emphatically announced its continued adherence to the definitional theory. 413 U.S. at 23. Justice Stevens' opinion in Young v. American Mini Theatres, 427 U.S. 50 (1976), a suit cliallenging a zoning ordinance, suggested that sexual material could be regulated, even if not obscene by Miller standards, where the governmental intrusion was less than that of a criminal sanction. In his dissent in Smith, Justice Stevens stated that Young "expressly rejected [the] premise that all nonobscenity is equally immune fron any governmental restraint and that all obscenity is equally vulnerable. 431 U.S. 291,316 (1977). Only three Justices in Young, however, joined the "variable obscenity" portion of his opinion. Further, the obscenity of the films involved in the Young litigation was not at issue. Whatever the eventual fate of the Stevens approach, it seems unlikely that the present Court exphicitly will move away froni Miller's comunitment to the definitional doctrine. Ginzburg, Mishkin, and Ginsberg, on the other liand, make pronounced variations in the community standard in particular factual situations. What further effect those cases inight lave on the definitional approach will not be specifically discussed.

27. Roth v. United States, 354 U.S. at 489.

28. Id. at 484.

29. Justice Breunan, who authored the Roth opinion, implied that the Court was espousing the view that only "ideas" were of sufficient value to merit first amendment protection:

There are certain well-defined and narrowly limited classes of speech, the prevention and punishment of which lrave never been thought to raise any Constitutional problem. These include the lewd and obscene. . . . It has been well observed that such utterances are of no essential part of any exposition of ideas, and are of such slight value as a step to truth that any benefit that may be derived from them is clearly outweighed by the social interest in order and morality.

354 U.S. at 485 (quoting Chaplinsky v. New Hampshire, 315 U.S. 568, 571-72) (emplrasis in original). This conclusion-that there is "value" only in the political or intellectual pursuit of truth-is borne out in the language of other Supreme Court opinions. See, e.g., Young v. American Mini Theatres, 427 U.S. 50, 54 (1976). The existence of the community standards criterion, as it is currently conceived by the Court, enables the factfinder in effect to substitute its own, possibly more expansive, view of what has "value." See text accompanying notes 64-66 infra.

30. Roth v. United States, 354 U.S. at 489 (1957). 
of the materials themselves was necessary to determine whether the test had produced the correct result. ${ }^{31}$ The definitional approach to obscenity initiated in Roth focused on whether the inaterial appealed to an average person's prurient imterest. The two key components of the "prurient appeal" imquiry - "community standards" and "average person"-were intended to dispel the worst tendencies of Hicklin and shield anything of value. It was uncertain, however, whether these components would sufficiently shield material of "value."32

Although prurient appeal was the core of the Roth inquiry, the Court, in subsequent opinions, seized on "the community" as a crucial, and conceptually isolable conponent of the constitutional test. Justice Frankfurter stated in one case that it was violative of due process not to require evidence of the community standards to be apphed at trial. ${ }^{33}$ Three years later, Manual Enterprises v. Day ${ }^{34}$ launched the persistent debate over whether the relevant "community" was the nation or some sinaller geographic unit. Justice Harlan, in an opinion joined only by Justice Stewart, argued that a federal statute ${ }^{35}$ should have a nationally uniform construction and thus that the standard apphed should be the same everywhere. He did not attenipt to articulate such a standard for future application by lower courts, however. Nor was such an attenupt inade two years later in Jacobellis $v$. Ohio, ${ }^{36}$ in which Justice Brennan, in a plurality opinion, argued for a national standard on the theory that "it is, after all, a national Constitution we are expounding."37 He reasoned that film, book, and magazine distributors would be unwilling to test local variations resulting from differing community standards, whose presence therefore would inhibit the creation and disseinination of protected expression. ${ }^{38}$ Again, only one Justice, Justice Goldberg, joined the opinion. Chief Justice Warren, joined by Justice Clark, argued that desirable diversity within the nation and the nonexistence of a national level of tolerance to sexually oriented inaterial called for the use of a inore local community standard. ${ }^{39}$ Justice Harlan wanted a

31. Id. at 496-98 (Harlan, J., concurring and dissenting). The scope of appellate review of the "constitutional fact" of obscenity is discussed in Part II infra.

32. Dissenting in Roth, Justices Black and Douglas took the view, which they ever afterward maintained, that any regulation of obscenity was constitutionally forbidden. 354 U.S. at 508 (Douglas, J., dissenting).

33. Smith v. California, 361 U.S. 147, 164-67 (1959). Apart froin the challenged materials themselves, evidence of community standards or, indeed, of "obscenity" in general, is clearly not now a constitutional requirement. See Paris Adult Theatre I v. Slaton, 413 U.S. 49, 56 (1973).

34. 370 U.S. 478 (1962).

35. 18 U.S.C. $\$ 1461$. See note 14 supra. None of the other Manual Enterprises opinions nuentioned the community standards issue.

36. 378 U.S. 184 (1964).

37. Id. at 193.

38. Id. at 192-96.

39. Id. at 200-01. 
national standard for federal statutes but would have permitted the states to use local standards. ${ }^{40}$

The Supreme Court did not take up the community standards issue again until Miller in 1973, but between 1962 and 1971 the Roth test underwent a confused transformation in other respects. Manual Enterprises added a new substantive element to the test: "patent offensiveness."41 More importantly, A Book Named "John Cleland's Memoirs of a Woman of Pleasure" v. Attorney General of Massachusetts ${ }^{42}$ added another: utter lack of "redeeming social value." 43 What had been the goal of the Roth obscenity test-to identify material lacking social value-became a separate inquiry within that test.

\section{Miller: The Current Obscenity Test}

Following Memoirs, the Supreme Court postponed for seven years its atteinpt to formulate a definite first ainendment obscenity doctrine. During this period, the Court issued a series of silent per curiain reversals whenever at least five Justices, applying their separate tests, found challenged materials to be protected by the first ainendment. ${ }^{44}$ Fimally, in the 1973 decision of Miller $v$. California, ${ }^{45}$ a majority of the Court, for the first time since Roth, agreed on a single formulation:

(a) whether "the average person, applying contemporary commumity standards" would find that the work, taken as a whole, appeals to the prurient interest, (b) whether the work depicts or describes, in a patently offensive way, sexual conduct specifically defined by the applicable state law, and (c) whether the work, taken as a whole, lacks serious

40. Id. at 203. See also Manual Enterprises v. Day, 370 U.S. 478, 488 (1962). A breakdown of the state and federal courts that apply each geographical standard is presented in F. SCHAUER, supra note 13 , at $119 \mathrm{n} .19$.

41. 370 U.S. at 482 (inagazines containing photographs of nude inales not obscene because not "so offensive on their face as to affront current commurity standards of decency"). Justice Harlan's opinion was later adopted as a constitutional decision, see A Book Named "John Cleland's Meinoirs of a Woinan of Pleasure" v. Attorney General of Massachusetts, 383 U.S. 413, 418 (1966); Jacobellis v. Ohio, 378 U.S. 184, 191-92 (1964), though it was a statutory imterpretation of 18 U.S.C. § 1461. See note 14 supra. The requirement of patent offensiveness as a separate element of the test had been suggested earher in the obscenity definition of the Model Penal Code: "Material is obscene if, considered as a whole, its predominant appeal is to prurient interest, that is, a shameful or morbid interest, in nudity, sex or excretion, and if in addition it goes substantially beyond customary limits of candor in describing or representing such matters." Model Penal CODE $\$ 251.4$ (P.O.D. 1962) (emphasis added). Note the similarity between the last clause of this quotation and the excerpt cited earlier, text accompanying note 15 supra, from Judge Hand's opmion in Kennerly v. United States 209 F. 119 (S.D.N.Y. 1913). The usefulness of patent offensiveness as an obscenity criterion has been severely criticized in Schauer, supra note 4.

42. 383 U.S. 413 (1966).

43. Id. at 419 .

44. See, e.g., Redrup v. New York, 386 U.S. 767 (1967); Miller v. Califormia, 413 U.S. 15, 21 n.3 (1973); Paris Adult Theatre I v. Slaton, 413 U.S. 49, 82 n.8 (1973) (Brennan, J., dissenting) (listing the 31 reversals).

45. 413 U.S. 15 (1973). 
literary, artistic, political, or scientific value. ${ }^{46}$

Part (a) is simply the Roth test shightly restated. Miller makes it apparent, however, that Roth's prurient appeal test, by itself, is not sufficiently selective as a "proxy rule" 47 to separate valuable material from the obscene. 48

Part (b) contains three hurdles to an ultimate finding of obscenity. First, the "patently offensive" requirement is carried over from Memoirs. Second, the material must portray " 'hard-core' sexual conduct."49 Miller provided some "plain examples" of what this might be:

(a) Patently offensive representations or descriptions of ultimate sex-

ual acts, normal or perverted, actual or simulated.

(b) Patently offensivc representations or descriptions of masturbation, excretory functions, and lewd exhibition of the genitals. ${ }^{50}$

Third, the prosecution must occur under a statute that specifies which hardcore conduct may not be depicted or described and that provides sufficient detail, either by statutory wording or prior judicial construction, ${ }^{51}$ to give fair warning to primary actors.

Finally, part (c) replaces the exacting "no redeeming social value" test from Memoirs with a "serious value" standard under which criminal liability ${ }^{52}$ was intended to be expanded, assuming that the applica-

46. Id. at 24 (citations omitted).

47. See text accompanying notes 29-31 supra.

48. "At a minimum, prurient, patently offensive depiction or description of sexual conduct must lave serious literary, artistic, political, or scientific value to merit First Amendment protection." 413 U.S. at 25 (1973) (emphasis added).

49. Id. at 27. This limitation had been presaged in Jacobellis v. Ohio, 378 U.S. 184, 197 (1964), by Justice Stewart who contended that it represented the first amendment limit. His famous "perhaps I could never succeed in intelligibly [defining what kinds of material are lardcore pornography], but I know it when I see it . . .," id., amounts to little more than an acknowledgement of the familiar tenet of even the earhest cases, that "obscenity" could not meaningfully be generalized into a fixed category. See text accoinpanying note 23 supra. The lardcore limitation was predicted by Professor Kalven in 1960. See Kalven, supra note 26, at 43.

50. 413 U.S. at 25 . The patent offensiveness of these examples is probably by way of emphasis, rather than duplication, of the offensiveness finding under one of the other Miller criteria. See Leventhal, The 1973 Round of Obscenity-Pornography Decisions, 59 A.B.A.J. 1261, 1263 (1973). This conclusion is buttressed by the fact that the "liardcore" determination is a question of law, whereas prurience and offensiveness are uniquely factual questions. See part II infra. For federal statutes, these examples have also become the list of proscribed conduct required under the Miller criterion of specificity. See United States v. Twelve 200-Ft. Reels of Super 8MM. Film, 413 U.S. 123, 130 n.7 (1973). But they do not exhaust all hardcore portrayals, which also include that which is "sufficiently similar to sucls material to justify similar treatment." Jenkins v. Georgia, 418 U.S. 153, I61 (I974).

51. Miller v. California, 413 U.S. at 24. Of course, a statute need not regulate all hardcore conduct portrayals. $C f$. Smith v. United States, 431 U.S. 291, 302 (1978) (state obscenity laws need not reach to the constitutional limit).

52. See, e.g., United States v. Harding, 507 F.2d 294 (10th Cir. 1974), cert. denied, 420 U.S. 997 (1975). The Miller Court was reacting in part to what it saw as the "virtually impossible" burden of proving a negative - the Memoirs "utterly without redeeming social value" formulation. Thus, the "serious" qualifier was added. Miller v. Califormia, 413 U.S. at 22-24. Whether the Court intended the change to make a quantitative or qualitative distinction has not been settled. 
ble statute reached the constitutional limit. ${ }^{53}$

The Miller formulation was set out as a three-part set of required "basic guidelines for the trier of fact," 54 but it actually requires the factfinder to make five separate determinations: prurient appeal, patent offensiveness, hardcore conduct, specifically defined conduct (specificity), and serious value. Community standards enter into the first two of these. While Miller made significant doctrinal alterations in the obscenity formulation, changing the "value" component and adding the hardcore and specificity requirenients, the chief importance of Miller and its progeny is that they altered the process of obscenity determination and the respective roles of the judge and jury. The role of commuinty standards has been instrumental in accomplishing these changes and, in turn, has been affected by the changes, as discussed in Part II.

II

\section{The Role of Community Standards Under MILLER}

Community standards retain an important role in the process of determining whether particular matter is obscene under Miller. Miller and its progeny ${ }^{55}$ liave split the obscenity decision into two parts; one is left exclusively to the factfinder and the other exclusively to the lawfinder. The community standards concept accomplishes this division.

The Supreme Court has viewed the prurient appeal and patent offensiveness components of the Miller test as "essentially questions of fact." 56 Factfinders are entitled to determine community standards

The Court has yet to apply the serious value test, though given a natural opportunity to do so in Jenkins v. Georgia, 418 U.S. 153 (1974), which involved a de novo review of the film Carnal Knowledge to determine its alleged obscenity. Although the record contained a considerable amount of critical acclaim for the movie, the Court chose to reverse the obscenity conviction on the ground that no "sexual conduct" was depicted. See text accoinpanying note 56 infra.

By setting out specific and exclusive varieties of value-hiterary, artistic, political, and scientific-the Court may have sought to check the anounalies raised by the prior use of "social value." See, e.g., United States v. One Reel of Film, 481 F.2d 206 (1st Cir. 1973), in which the argunent was made that the film Deep Throat had educational and psychological-release value. This sort of attack "saves" otherwise obscene material precisely because it is pornographic. As a result, perhaps, "educational" was oinitted from the list of values. But $\mathcal{c}$. Leventhal, supra note 50, at 1264, in which Judge Leventhal argues that the Court must have intended the enumerated values to subsume "educational" worth.

53. Every federal obscenity law that has been before the Court has been so construed. See, e.g., Sinith v. United States, 431 U.S. 291 (1977) (construing 18 U.S.C. $§ 1461$, see note 14 supra); Hanling v. United States, 418 U.S. 87 (1974); United States v. Orito, 413 U.S. 139 (1973) (construing 18 U.S.C. $\$ 1462$, penalizing movement of obscene material in interstate conunerce); United States v. Twelve 200-Ft. Reels of Super 8MM. Film, 413 U.S. 123 (1973) (construing 19 U.S.C. $\S 1305(a)$, civil statute authorizing destruction of imported obscene inatter); United States v. Reidel, 402 U.S. 351 (1971); Roth v. United States, 354 U.S. 476 (1957). See generally F. SCHAUER, supra note 13 , at 169-91.

54. 413 U.S. at 24 .

55. See generally cases cited in note 2 supra.

56. Miller v. California, 413 U.S. at 30. 
solely on the basis of their own knowledge; ${ }^{57}$ thus, there is no appellate review of these decisions. ${ }^{58}$ Moreover, the factfinder's conceptualization of a hypothetical "average person" is not subject to any mandatory geographical referent. ${ }^{59}$ Thus, although an obscenity finding is reviewable on other grounds, the prurience and offensiveness components are effectively shrouded froin appellate scrutiny. ${ }^{60}$

The three other components of the Miller test-hardcore conduct, specificity, and serious value-are questions of law. Before the factfinder is even permitted to review challenged material for prurience or offensiveness, the judge must find the material to be hardcore. Similarly, whether the work depicts or describes sexual conduct specifically proscribed by state law is solely a question of constitutional law and statutory construction. ${ }^{61}$ And whether the work as a whole lacks serious hiterary, artistic, pohtical, or scientific value is also a legal question, ${ }^{62}$ although the appropriate means of assessing "serious value" has yet to be estabhished. ${ }^{63}$

In sum, the Miller apparatus divides the obscenity issue into legal

57. See, e.g., Paris Adult Theatre I v. Slaton, 413 U.S. 49, 56 (1973), where the trial court, sitting without a jury, viewed the allegedly obscene films. See also text accompanying note 33 supra.

58. This is assuming that the material itself is placed in evidence, see Paris Adult Theatre I v. Slaton, 413 U.S. 49, 56 (1973), and that "deviant groups" are not involved. See Mishkin v. New York, 383 U.S. 502 (1966). Even where a "deviant" audience standard is involved, the evidentiary requirements appear to be minimal. See Pinkus v. United States, 98 S. Ct. 1808, 1814 (1978).

59. Miller held that a reference to a statewide community was constitutionally adequate to perform the moderating functions of objectivity, temporal flexibihity, and attention to neither atypically sensitive nor callous persons. 413 U.S. at 34 (1973). See text accoinpanying notes 15-24 supra. Hamling v. United States, 418 U.S. 87, 102-10 (1974), though recognizing Miller's disapproval of a national standard, held that a trial court's use of the phrase in jury instructions was harmless error, that the instructions had otherwise performed the proper moderating functions, and that refusal based on the error in the choice of standard to admit evidence relevant to a smaller community was constitutionally permissible. Jenkins v. Georgia, 418 U.S. 153, 157 (1974), approved a jury instruction that contained no geographical reference; geographical specification was not required. Smith v. United States, 431 U.S. 291 (1977), ruled that a state statute that left obscenity unregulated as to adults was not conclusive in the determination of the community standard. Thus, jury imstructions have been the only real handle for judicial review. See, e.g., Pinkus v. United States, 98 S. Ct. 1808, 1811 (1978) ("children" should not be among those groups-young and old, sensitive and insensitive, religious and irreligious-that jurors should be instructed to consider in arriving at their conception of "coinınunity standards").

60. Jenkins v. Georgia, 418 U.S. 157 (1974), was the first case following Miller in whieh the Supreme Court conducted a de novo review of challenged material. The view that Jenkins was a case of judicial redetermination of the offensiveness element, see Schauer, supra note 4, at 20, is not borne out by the language of the opmion. 418 U.S. at 161.

61. See, e.g., United States v. Twelve 200-Ft. Reels of Super 8MM. Film, 413 U.S. 123, 130 n.7 (1973).

62. See United States v. Heyman, 562 F.2d 316 (4th Cir. 1977) (reversal required because jurors were instructed to determine serious value according to commumity standards). See also Smith v. United States, 431 U.S. 291, 305 (1977).

63. What specific interpolations are most appropriately to be made between the viewing of material and the conclusion regarding "value" is a matter for future jurisprudence. It may be that the Court feels none are needed as long as the Roth "proxy rule" for prurient appeal is a part of 
and factual questions. The prurient appeal "proxy rule," which previously was the sole constitutional inquiry, has been relegated by the inscrutable community standards test to the uncertain status of a purely factual question that is not subject to direct judicial review.

The community standards concept, at least as the Suprenne Court currently conceives it, provides a check on the legal question components of the Miller test. Because prurience and offensiveness are questions of fact, a jury ${ }^{64}$ can counter the great power of trial court judges to determine that the challenged naterial is hardcore and lacks serious value. ${ }^{65}$ The community standards concept thus protects expression by permitting the jury, as a representative of the community, and not only the judge, to be the final determiner of what is obscene. ${ }^{66}$

the Miller test. If so, both the factfinder and the lawfinder are relatively free to apply their own perceptions of "value."

It has been suggested that a possible formulation of the offensiveness test asks whether the average person would be offended by the availability of the challenged materials, not by the materials themselves. See F. SchaUER, supra note 13, at 133. This, if permitted, clearly accommodates much of the "variable obscenity" concept and invites a forthright "value" judgment. "Whether or not the question is put directly by the judge, indications are it is the question the jury may be answering." Levanthal, Preface to An Empirical Inquiry into the Effects of Miller v. California on the Control of Obscenity, 52 N.Y.U. L. REv. 810, 817 (1977).

64. Defendants in obscenity cases usually prefer judges to juries, however. See F. ScHAUER, supra note 13, at 267; Lockhart \& McClure, supra note 4, at 109 n.596; O'Meara \& Shaffer, supra note 4 , at 10 . This may be due to obscenity defendants' perception of judicial discomfiture with the community standards test and a concomitant hesitancy to ban or convict. See United States v. 2200 Paper Back Books, 565 F.2d 566, 570 (9th Cir. 1977), Cf. United States v. Various Articles of Obscene Merchandise, Schedule No. 1303, 562 F.2d 185, 189-91 (2d Cir. 1977) ("In reality, no judge or jury can be expected to determine 'community standards' with respect to Exhibit 8"). See Smith v. United States, 431 U.S. 291, 314 (Stevens, J., dissenting): "The best anyone can do is give his or her personal reaction to it. . . . The District Court will have to serve as a conposite for a Southern District jury."

65. See, e.g., United States v. One Reel of 35MM. Color Motion Picture Film Entitled "Sinderella," 491 F.2d 956, 959 (2d Cir. 1974). The court of appeals held that the trial judge, trying the case without a jury, was entitled to appraise local contemporary standards as he believed they might exist and to apply them to the challenged film. In this case the court reasoned: "For some reason films quite obviously obscene are being allowed, permitted or tolerated by local law enforcement agencies. . . . [This animated puppet cartoon] could at best only produce a brief community smirk. . . [ [and] should be banned."

This is especially important in view of the Miller Court's attempt to minimize the Supreme Court's role in reviewing obscenity determinations. See Note, Class Actions, supra note 4, at 1839 40, which argues that Miller was in large part the Court's reaction against what it saw to be an undesirably "top-heavy" number of summary reversals, casting it "in the role of an unreviewable board of censorship for the 50 states, subjectively judging each piece of material brought before [the Court]." Miller v. California, 413 U.S. 15, 21 n.3 (1973).

Whatever the Court's motivations may have been, it is clear that the Miller system places great rehance on factfinders. The use of the tern "subjectively" in the quoted passage may simply be a casual use of language. It inay be, on the other hand, an expression of the Court's belief in its own inability to carry out the "objectivity" function of the community standards test. See text accompanying notes 20-22 supra.

66. This may help to account for the results of a recent extensive study of the effects of Miller on the availability of sexually explicit material, success of prosecutions, and perceptions of prosecutors of the relative ease of convictions. Project, An Empirical Inquiry into the Effects of Miller v. 


\section{III}

\section{Community Standards Problems Under Miller}

\section{A. Geographical Uncertainty}

Much of the commentary critical of the Miller Court's concept of contemporary community standards has been spawned by the awkward and hesitant manner im which the Court has attempted to extricate itself from the residue of the geographical debate of the 1960's. The Court hedged as it rejected the "national standards" approach and implicitly approved the "balkanization" of obscenity adjudication. The Court's empliasis on the geographical reference point for community standards has invited confusion. The belief that various "community standards" exist in different places ${ }^{67}$ like different species of fauna has engendered a considerable body of complex tangential issues of change of venue, conflicts of law, and the ability of jurors to discern the contours of a "standard" in a place far from their residence. ${ }^{68}$ But on a functional level, the confusion lias been exaggerated. If the jury is not required to define the community standards that it applies, it is probably not necessary to specify the geographical community from which the jury derives its undefined standards. ${ }^{69}$

\section{B. Vagueness and Notice Problems}

The absence of a fixed definition and specification of community standards, both substantively and geographically, contributes to problems of vagueness and notice. Perhaps the most persistent quarrel witli the Supreme Court's obscenity tests has been that they are fatally vague. ${ }^{70}$ In his dissent in Paris Adult Theatre $I v$. Slaton, ${ }^{71}$ Justice

California on the Control of Obscenity, 52 N.Y.U. L. REv. 810, 858, 877, 891-915 (1977). This study indicates that, as a practical matter, Millcr's impact has been insignificant and, in fact, more pornography is available than prior to 1973. These findings were unexpected in the wake of the Court's expectations that the "serious value" test represented an expanded ability to convict under obscenity laws.

67. See Miller v. California, 413 U.S. 15, 30(1973): "It is neither reahistic nor constitutionally sound to read the First Amendment as requiring that the people of Maine or Mississippi accept public depiction of conduct found tolerable in Las Vegas, or New York City."

68. See, e.g., Haim v. United States, 554 F.2d 474 (5th Cir. 1977), cert. denied, 98 S. Ct. 275 (1977); Reed Enterprises v. Clark, 278 F. Supp. 372 (D.D.C. 1967), affd, 390 U.S. 457 (1968) (per curiam); Scliauer, Obscenity and the Conflict of Laws, 77 W. VA. L. REv. 377 (1975); Shugrue, An Atlas for Exploring Community Standards, 7 Creighton L. REv. 157 (1974); Comment, United States v. MacManus-Transfer of Venue and the Contemporary Community Standards Test in Federal Obscenity Prosecutions, 52 N.Y.U. L. Rev. 629 (1977).

69. Of course, it may be imaginatively lelpful for a juror to lave some locale in mind in order to come up with the "average" person, as opposed to a personal, subjective judgment.

70. A law is unconstitutionally vague under the due process clause of the fourteenth amendment if it provides a reasonably intelligent person with no knowledge of what conduct the law prohibits. See generally Note, The Void-for-Vagueness Doctrine in the Supreme Court 109 U. PA. L. REv. 67 (1960). In the first amendment area, vagueness is seen as especially pernicious because it causes the public to err on the side of caution and forgo protected expression. 
Brennan, author of the chief opinions in Roth, Memoirs, Ginzburg $v$. United States, ${ }^{72}$ and Ginsberg v. New York ${ }^{73}$ concluded that obscenity was intrinsically vague as a concept and thus constitutionally unworkable. Since then, Justices Stewart and Marshall, and Justice Stevens in criminal cases, consistently have joined him in this view.

Prior to Miller, challenges on vagueness grounds were met with brief rebuffs. ${ }^{74}$ Having made an explicit move toward providing greater certainty in the specificity requirement in Miller, the Supreine Court stated in United States v. Twelve 200-Ft. Reels of Super 8MM. Film $^{75}$ that the Miller examples of the types of expression that may be proscribed were sufficiently precise linguistically to provide fair notice to primary actors. ${ }^{76}$

Whatever the relative precision of the other components of the Miller test, the community standards concept has never been defended as being sufficiently clear. Rather, the Supreme Court's attitude has been that the specificity requirement satisfies the demands of both the first amendment and the due process clause.

The vagueness of the community standards concept inight be tolerable if the specificity requirement were taken seriously. Ward $v$. Illinois, ${ }^{77}$ however, indicates that this may not be the case. In Ward, a defendant was convicted prior to Miller under a state obscenity statute that did not specifically proscribe the conduct for which he was convicted. He challenged the statute for vagueness. The Supreme Court simply held that under pre-Miller applications of the statute, he should have known that his conduct was subject to criminal sanction. The Court went on to state that the Constitution did not require that an obscenity statute include an exhaustive list of the types of material that it proscribes. ${ }^{78}$ The opinion severely undercuts Miller's self-acclaim as the provider of public certainty in the obscenity area. ${ }^{79}$

71. 413 U.S. 49, 73-114 (Brennan, J. dissenting).

72. 383 U.S. 463 (1966).

73. 390 U.S. 629 (1968).

74. See, e.g., Smith v. United States, 431 U.S. 291, 312 (1977).

75. 413 U.S. 123 (1973).

76. The state statutes that the Miller Court offered as examples of the constitutionally required amount of statutory detail are considerably more precise than the Miller examples themselves, which apparently view "lewd exhibition of the genitals," for example, as falling within hardcore sexual conduct. Jenkins v. Georgia, 418 U.S. 153 (1974). Judge Leventhal's opinion in Huffman v. United States, 470 F.2d 386 (D.C. Cir. 1971), represents perhaps the most precise line drawing yet done in the obscenity area. His review of the materials approved or condemned by the Supreme Court during the post-Memoirs period led to a standard that distinguished "inminent" and "ongoing" sexual activity, "single" or "dual" photos, etc. The Supreine Court has never been nearly as precise, even in construing federal statutes.

77. 431 U.S. 767 (1977).

78. Id. at 773 .

79. See id. at 777 (Stevens, J., dissenting) (removal of the "cornerstone" of the Miller structure-the specificity requirement-hastened its downfall). 
The Court also seems reluctant to require the same degree of statutory detail from Congress as Miller requires of state statutes. ${ }^{80}$ Until it does so or is willing to supply its own language of conduct that may not be depicted, the specificity element of the Court's obscenity structure will not provide the solution to the vagueness and notice problems. Nor is the solution found in the serious value test. If anything, in its present status, that test contributes to the uncertainty and unpredictability of the definition of obscenity. The prospective indetermmacy of any judgment made under community standards, especially an undefined and unreviewed one, can be balanced only by almost hairlme specificity in other parts of the Miller test. Such specificity is clearly lacking.

\section{CONCLUSION}

Putting aside the issue of whether any regulation of sexual expression is desirable, does the community standards concept, as applied im the Miller test, contribute to the Supreme Court's first amendment goal of properly fixing "the critical point in the compromise between candor and shame"? ?1 $^{81}$ Is it desirable to retain community standards as part of the Miller scheme? ${ }^{82}$

By giving the factinder virtually unchecked discretion over the prurient appeal and patent offensiveness determinations, and thus the ability to undercut a lawfinder's opinion that challenged naterial is obscene, the community standards concept aligns the Miller structure in a way that does not seein unduly to impinge on expression and may even protect expression at the point of adjudication. The concept does, however, contribute to the nagging problems of vagueness and lack of fair notice to those actors whose activities have not yet reached the point of judicial scrutiny.

Abolition of the community standards concept certainly would reduce conceptual clutter, but it is the Supreme Court's own ambivalence, not inerely the language of its opinions, that has created inuch of the confusion. The Court still can break off cleanly from the encrustations of the geographical debate ${ }^{83}$ while retaining the cautionary value of the "community standards" instruction. And, at least to some ex-

80. The Miller examples are notably less precise anatomically than the state examples cited in the majority opinion. See 413 U.S. at 24 n.6.

81. See Kennerly v. United States, 209 F. 119, 120-21 (S.D.N.Y. 1913); text accompanying notes 15-24 supra.

82. Professor Schauer takes the position that the concept has no place in the definitional obscenity theory that is adequately served by the value and prurience tests, and indeed that "offensiveness" is itself a superfluous criterion which necessitated the community standards test. Schauer, supra note 4, at 14-23.

83. Snith v. United States, 431 U.S. 291 (1977), and Pinkus v. United States, 98 S. Ct. 1808 (1978), have taken long steps in this direction. Justice Blackmun stated in Smith that community 
tent, the Court can offset the vagueness problems that are inherent in the commumity standards concept by sharpening the focus of the other elements of the Miller test, especially the serious value and hardcore conduct components and the specificity requirement. On balance, the community standards concept serves a useful role in the Miller framework that outweighs the problems created by it. The concept should, therefore, be retained.

Chris Hunt*

standards cannot legislatively be defined. Pinkus reemphasized the "reasonableness" analogy, though perhaps "protesting too much" at the same time. Id. at 1813-14.

* A.B. 1972, Harvard College; third-year student, Boalt Hall School of Law. 
